\title{
PERAN ULASAN PRODUK DAN FOT PRODUK YANG DITAMPILKAN PENJUAL PADA MARKETPLACE SHOPEE TERHADAP MINAT BELI PRIA DAN WANITA
}

\author{
The Role of Product Reviews and Product Photos Displayed by Sellers at Shopee \\ Marketplace Against Men's and Women's Purchase Interests \\ ${ }^{1}$ Intan Ratu Servanda*, ${ }^{2}$ Putri Reno Kemala Sari, ${ }^{3}$ Nova Adhitya Ananda \\ Manajemen, Fakultas Ekonomi dan Bisnis, Universitas \\ Teknologi Sumbawa \\ Jl. Raya Olat Maras, Batu Alang, Moyo Hulu, Kabupaten \\ Sumbawa \\ Email: intanservanda07@gmail.com
}

\begin{abstract}
ABSTRAK
Penelitian ini bertujuan untuk mengetahui Peran Ulasan Produk dan Foto Produk yang Ditampilkan Penjual pada Marketplace Shopee Terhadap Minat Beli Pria dan Wanita. Variabel yang digunakan yaitu, Ulasan Produk, Foto Produk yang Ditamilkan Penjual dan Minat Beli. Populasi adalah seluruh mahasiswa dan mahasiswi aktif Universitas Teknologi Sumbawa dengan sampel sebanyak 100 orang. Instrumen yang digunakan adalah kuesioner dan alat analisis yang digunakan adalah SPSS. Jenis data yakni data primer yang didapat dari hasil pengisian kuesioner dengan penilaian skala likert 4 poin. Uji prasyarat meliputi uji normalitas, uji heteroskedastisitas, dan uji multikolinearitas serta teknik analisis yang digunakan yakni analisis regresi linear berganda. Hasil penelitian ini menunjukan bahwa variabel Ulasan Produk dan Foto Produk yang Ditamilkan Penjual memiliki pengaruh yang signifikan terhadap minat beli. Kemudian, wanita memiliki responsive yang lebih tinggi terhadap Ulasan Produk dan Pria memliki responsive yang lebih tinggi terhadap foto produk yang ditampilkan penjual. Dalam penelitian ini juga menunjukkan bahwa wanita memiliki minat beli yang lebih tinggi pada marketplace Shopee.
\end{abstract}

Kata Kunci : Ulasan produk, Foto produk yang ditampilkan penjual, Minat beli

\begin{abstract}
This study aims to determine the Role of Product Reviews and Product Photos Displayed by Sellers at Shopee Marketplace Against Men's and Women's Purchase Interests. The variables used are Product Reviews, Product Photos from the Seller and Purchase Interests. The population is all active students of Sumbawa Technology University with a sample of 100 people. The instrument used was a questionnaire and the analytical tool used was SPSS. The type of data is primary data obtained from the results of filling out the questionnaire with a 4-point Likert Scale assessment. The prerequisite tests include normality test, heteroscedasticity test, and multicollinearity test and the analysis technique used is multiple linear regression analysis. The results of this study indicate that the variable product reviews and product photos that the seller is having a significant influence on buying interest. Then, women have a higher responsiveness to Product Reviews and Men have a higher responsiveness to the product photos displayed by the seller. In this study also showed that women have a higher buying interest in the Shopee marketplace.
\end{abstract}

Keywords : Product reviews, Product photos displayed by the seller, Purchase interest 


\section{PENDAHULUAN}

Perkembangan teknologi internet terus berkembang hingga saat ini mempengaruhi jalannya kegiatan bisnis dimana membeli dan berbelanja barang atau jasa kini dapat dilakukan melalui media daring yang dikembangkan dalam bentuk aplikasi yang dapat diunduh melalui smartphone atau disebut juga dengan ecommerce yaitu penggunaan jaringan komunikasi dan komputer untuk melakukan bisnis ( Fitri, 2017).

E-commerce yang kini digunakan sebagai wadah bagi para pebisnis untuk menawarkan produk atau jasanya secara daring lebih dapat menjangkau pelanggan secara global. Dalam sebuah penelitian yang dilakukan oleh Abebe (2014) menunjukan bahwa perusahaan yang mengadopsi e-commerce lebih mudah menjual produknya dibandingkan perusahaan yang tidak mengadopsi e-commerce.

Salah satu yang merupakan bagian dari ecommerce adalah Marketplace, yaitu pasar elektronik yang menyediakan tempat untuk banyak penjual dan pembeli melakukan berbagai jenis transaksi jual beli barang ataupun jasa layaknya di sebuah pasar biasa namun dilakukan secara virtual (Efraim et al. 2012). Memiliki konsep yang kurang lebih sama dengan pasar tradisional, tugas dari marketplace itu sendiri adalah menyediakan tempat bagi para penjual yang ingin berjualan dan membantu mereka untuk bertemu pelanggan kemudian melakukan transaksi dengan lebih sederhana dan mudah. Kini marketplace semakin banyak diminati karena kemudahan dan kenyamanan dalam penggunaannya.

Salah satu Marketplace yang kini juga memiliki aplikasi yang sedang marak digunakan adalah Shopee. Shopee adalah satu dari banyak website atau Marketplace yang memanfaatkan peluang bisnis e-commerce dengan meramaikan segmen toko melalui aplikasi di telepon pintar. Melalui aplikasi yang ada di telepon pintar mereka dapat mempermudah transaksi jual beli. Selain Shopee ada juga Tokopedia, Bukalapak, Lazada id, Blibli, Orami, JD.id, Bhineka, Sociolla, Zalora, dan masih banyak lagi.

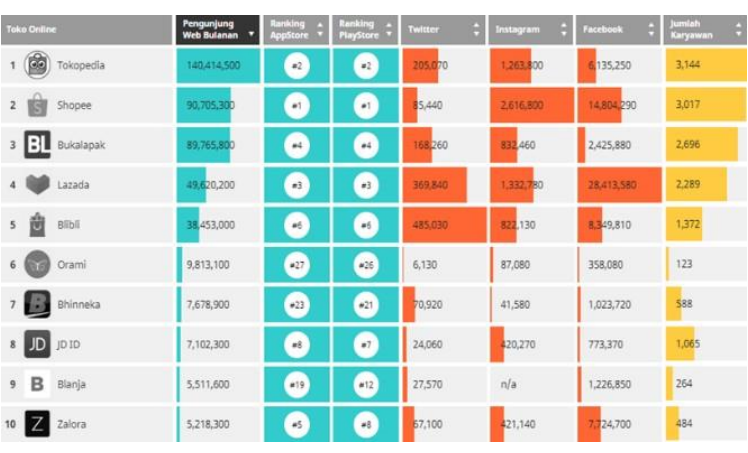

Sumber : (Iprice.id 2019)

Gambar 1.1 Peta E-Commerce Indonesia Quartal 2 Tahun 2019 Menurut Data dari Iprice.co.id

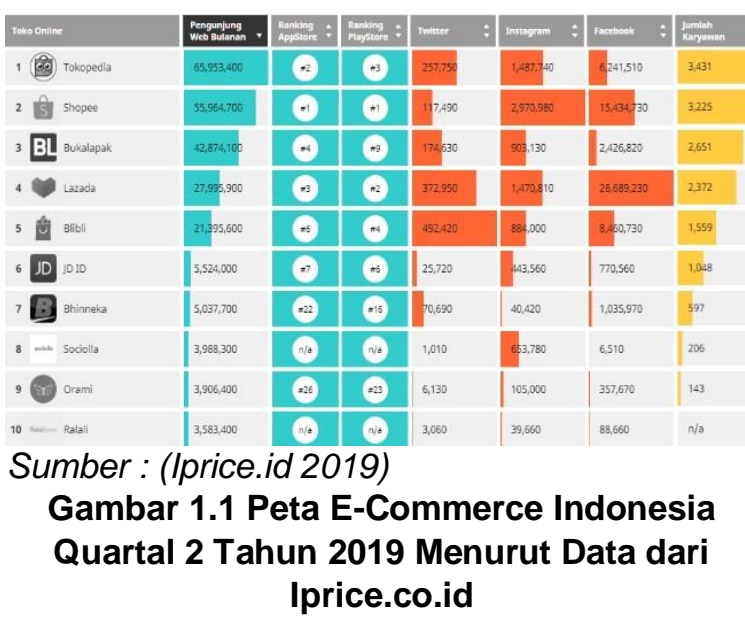

Dari data penelitian yang telah dilakukan oleh iprice.co.id diatas menunjukan bahwa Shopee merupakan aplikasi belanja daring atau marketplace paling popular nomor 2 di Indonesia setelah tokopedia pada quartal 2 dan 3 tahun 2019. Meskipun berada pada nomor 2, dapat dilihat bahwa Shopee konsisten berada pada ranking 1 untuk kategori pada toko aplikasi yang ada di iphone OS dan toko aplikasi yang ada di android pada quartal 2 dan 3 tahun 2019. Shopee juga memilik pengikut yang paling banyak pada Instgram dan Facebook. Semua hal tersebut dapat dicapai perusahaan Shopee karena menyediakan aplikasi yang memudahkan penggunanya untuk membeli ataupun menjual produk dengan menyediakan informasi yang lengkap mengenai reputasi penjual sehingga konsumen bebas membandingkan dan memilih produk yang diinginkan. Uang yang telah di transfer saat terjadi pembelian antara konsumen dan penjual pun tidak semata langsung diberikan ke penjual, melainkan melalui proses dan 
perantara pihak Shopee, sehingga jika suatu saat terdapat penjual nakal yang ingin menipu pelanggan, uang yang telah di transfer pun dapat di kembalikan lagi ke pelanggan.

Adapun keunggulan dari Shopee adalah Marketplace pertama bagi konsumen-kekonsumen $(\mathrm{C} 2 \mathrm{C})$ yang berani menawarkan gratis biaya kirim ke seluruh Indonesia tanpa minimal pembelian untuk produk yang bertanda khusus pada awal kemunculannya berdasarkan informasi dari akun Facebook resmi milik Shopee. Namun dengan berjalannya waktu, kini Shopee sudah menetapkan batas minimum kepada pembeli untuk dapat berpartisipasi dalam program ini. Selain memiliki sistem Marketplace C2C Shopee juga menerapkan sistema B2B (Business to Business). Shopee Mengklaim bahwa ia merupakan Marketplace dengan tempat belanja termurah dan memberikan garansi harga termurah khusus di Asia Tenggara terutama Indonesia, dimana apabila konsumen menemukan produk lain dengan harga lebih murah dari yang ditawarkan Shopee, konsumen berhak mengklaim uang kembali sebesar 2 kali lipat dari harga barang sebelumnya. Selain itu, riset iPrice.co.id menunjukkan Shopee menjadi aplikasi e-commerce dengan jumlah pengguna aktif bulanan atau Monthly Active Users (MAU) dan jumlah unduhan terbesar di Asia Tenggara. Yang perlu diketahui bahwa Shopee tidak hanya hadir di pasar Indonesia saja, tetapi sebelumnya telah hadir di Malaysia, Singapura, dan juga Vietnam (Facebook.com, 2019).

Fenomena belanja daring akan semakin pesat pertumbuhannya dan menjadi pilihan bagi sebagian besar orang dikarenakan belanja melalui dunia maya dapat menghemat waktu tanpa perlu mengunjungi lokasi perbelanjaan dan aman. Dengan menjadi toko daring terpopuler nomor 2 di Indonesia, pada quartal 3 Shopee mengalami penurunan pengunjung pada website nya. Penurunan jumlah pengunjung menjadi masalah yang harus diperhatikan karena akan menjadi ancaman bagi perusahaan itu sendiri, ditambah lagi dengan semakin ketatnya persaingan dalam e-commerce di Indonesia saat ini. Perusahaan harus mencari penyebab dan solusi atau strategi untuk memasarkan dan mencegah resiko penurunan penjualan lebih lanjut lagi sehingga dapat meningkatkan lagi minat beli konsumen. Minat Beli adalah proses pemenuhan keinginanan konsumen untuk membeli suatu barang atau jasa yang didasari beberapa pertimbangan sebelum membentuk pilihan (Pramono et al., 2012). Beberapa faktor yang mempengaruhi minat beli adalah ulasan produk (Wei Di et al. 2014) dan foto produk (Sung Ho et al., 2014).

Ulasan produk adalah ulasan, komentar berupa kata atau gambar yang diberikan oleh konsumen seteah barang yang telah dibeli sampai pada tangan konsumen. Ulasan produk yang merupakan satu dari banyak fitur unik pada toko daring juga dapat disebut electronic word of mouth (eWOM), dimana kualitas kata pada eWOM yang disampaikan melalui ulasan produk dapat memberikan pengaruh lebih besar ketika konsumen terlibat langsung didalamnya (Eun-Ju \& Yun Shin 2014).

Foto produk yang ditampilkan penjual sendiri adalah hal utama yang akan dilihat oleh konsumen ketika mengunjungi toko daring yang ada di marketplace Shopee. Belanja daring sendiri merupakan bagian penting dari perdagangan. Kenyamanan adalah keuntungan terbesar dari belanja daring, tetapi ketidakmampuan untuk melihat dan menyentuh langsung produk adalah kelemahan dari belanja daring. Oleh karena itu, gambar dapat memainkan peran penting dalam mengatasi ketiakmampuan konsumen untuk melihat dan menyentuh produk secara langsung. Gambar visual adalah alternatif yang baik untuk menyampaikan infomasi penting ke pengguna belanja daring dan mempengaruhi pilihan mereka (Wei Di et al. 2014). Oleh sebab itu tentunya para pemilik toko daring yang ada di marketplace Shopee pastinya akan memasang foto produk yang menarik dan indah di pandang agar para konsumen tertarik dan timbul minat beli.

Dengan adanya dua faktor di atas selain memiliki minat beli tentunya antara pria dan wanita memiliki perbedaan pesepsi terkait ulasan produk dan foto produk yang di tampilkan. Persepsi sendiri adalah proses yang menyangkut masuknya pesan atau informasi kedalam otak manusia, melalui persepsi manusia terus menerus mengadakan hubungan dengan lingkungannya dan dilakukan lewat inderanya, yaitu indera pengelihat, pendengar, peraba, perasa,dan pencium (Slameto, 2010).

Dari fenomena tersebut peneliti ingin melihat apakah ulasan produk dan foto produk yang di tampilkan marketplace Shopee memiliki 
pengaruh yang signifikan atau tidak terhadapat munculnya minat beli dan apakah terdapat perbedaan persepsi antara pria dan wanita terkait peranan ulasan produk dan foto produk yang ditampilkan penjual pada marketplace Shopee.

Berdasakan uraian di atas, maka peneliti tertarik untuk melakukan penelitian yang berjudul "Peranan Ulasan Produk dan Foto produk yang Ditampilkan penjual pada Marketplace Shopee Terhadap Minat Beli Pria dan Wanita" studi dilakukan pada mahasiswa aktif Universitas Teknologi Sumbawa yang pernah menggunakan aplikasi Shopee.

\section{RUMUSAN MASALAH}

1. Bagaimana pengaruh ulasan produk pada marketplace Shopee terhadap munculnya minat beli?

2. Bagaimana pengaruh foto produk yang ditampilkan penjual pada marketplace Shopee terhadap munculnya minat beli?

3. Bagaimana responsif wanita terhadap ulasan produk?

4. Bagaimana responsive pria terhadap foto produk yang ditampilkan penjual?

5. Bagaimana minat beli wanita di Marketplace Shopee?

\section{HIPOTESIS PENELITIAN}

Dalam penelitian Eun-Ju \& Yun Shin (2014) menyatakan bahwa kualitas ulasan yang baik memberikan pengaruh signifikan pada niat pembelian. Begitu juga pada penelitian yang dilakukan oleh Sung Ho et al. 2015 menyatakan bahwa ulasan produk yang diberikan konsumen memiliki dampak yang signifikan terhadap penjualan produk. Hal tersebut menunjukan bahwa penjual yang ingin meningkatkan penjualan produknya harus secara aktif mengumpulkan ulasan produk dari konsumen. Sehingga berikut hipotesis terkait;

H1: Ulasan produk pada marketplace Shopee berpengaruh terhadap minat beli

Dalam penlitian Wei Di et al. (2014) yang meneliti tentang peran gambar dalam ecommerce menemukan bahwa gambar atau informasi multimedia lainnya dapat membantu meningkatkan tingkat transaksi dalam belanja daring. Dalam penelitian Xin L et al. (2016) juga menunjukkan hasil bahwa persentasi produk visual dapat mempengaruhi perilaku belanja konsumen ketika estetika visual disampaikan melalui foto produk yang dapat ditangkap dengan bantuan teknik pemrosesan gambar modern. Adapun hipotesis terkait foto produk;

H2: Foto produk yang ditampilkan penjual pada marketplace Shopee memiliki pengaruh terhadap munculnya minat beli

Dalam penelitian Xiaolin et al. (2018) menunjukan bahwa minat beli pria lebih dipengaruhi oleh interaktivitas situs web daripada wanita. Sebaliknya, minat beli wanita lebih dipengaruhi oleh kejelasan, diagnostik informasi yang diberikan penjual, dan risiko yang dirasakan. Dalam penelitian Kem Z.K. et al. (2014) yang juga membahas mengenai perbedaan gender dalam persepsi dan sikap terhadap ulasan yang tidak konsisten atau buruk di toko daring menemukan bahwa ulasan yang tidak konsisten atau buruk lebih mempunyai pengaruh yang signifikan terhadap wanita dari pada laki-laki. Berikut hipotesis terkait perbedaan persepsi dan pengambilan keputusan pria dan wanita:

H3: Wanita memiliki tingkat responsif yang lebih tinggi terkait ulasan produk.

$\mathrm{H} 4$ : Pria memiliki tingkat responsif yang lebih tinggi terkait foto produk yang ditampilkan penjual

Dalam penelitian Laksmitha dan Agung (2014) yang meneliti mengenai pengaruh perbedaan jenis kelamin dan kontrol diri terhadap keutusan pembelian impulsif produk parfum menunjukan bahwa konsumen perempuan memiliki kecendurangan yang lebih tinggi untuk melakukan pembelian impulsif dibandingkan dengan pria. Diba (2014) juga mengungkapkan dalam penelitiannya bahwa wanita cendrung memiliki prilaku pembelian impulsif dan memiliki peranan kontrol diri yang buruk dibandingkan pria yang mengakibatkan pria pria hanya memeli barang berdasarkan kebutuhan dan kesenangan saja. Berikut hipotesis terkait perbedaan minat beli pada pria dan wanita:

H5: Wanita memiliki minat beli yang lebih tinggi pada Marketplace Shopee. 


\section{DEFINISI OPERASIONAL}

1. Minat Beli $(Y)$ adalah proses pemenuhan keinginanan konsumen untuk membeli suatu barang atau jasa yang didasari beberapa pertimbangan sebelum membentuk pilihan (Pramono et al., 2012). Adapun idikator yang mempengaruhi minat beli menurut Ferdinand (2009) minat beli seseorang dapat dilihat dari beberapa indikator, yaitu:
a. Minat transaksional
b. Minat refrensial
c. Minat Prefensial
d. Minat eksploratif

2. Ulasan Produk $\left(X_{1}\right)$, menurut pendapat dari Kosasih (2014), teks ulasan merupakan teks yang berisi tafsiran, penilaian dan kritik atau komentar mengenai objek tertentu yang dapat berbentuk lisan ataupun tulisan. Indikator ulasan produk yaitu;
a. Rating (Nathania 2018)
b. Evaluasi Produk (Eun-Ju \& Yun Shin 2014)
c. Valensi dari Opini (Goyette 2010)

3. Foto produk yang Ditampilkan penjual $\left(X_{2}\right)$ Menurut Cecep Kustandi dan Bambang Sutjipto (2013) adalah media yang berfungsi untuk menyampaikan pesan yang disampaikan dituangkan melalui simbolsimbol komunikasi visual melalui gambar yang menyangkut indera penglihatan. Indikator yang mempengaruhi foto produk sendiri. Adapun indikator foto produk dalam penelitian ini yaitu :
a. Informasi, (Xin L et al., 2016)
b. Emosional yang tersirat, (Xin L et al. 2016)
c. Estetika Visual (Xin L et al., 2016)
d. Pose Model atau Objek (Nugraha 2016)

\section{METODE PENELITIAN}

Jenis penelitian dalam penelitian ini adalah penelitian kuantitatif asosiatif. penelitian kuantitatif adalah alat meneliti yang menggunakan populasi atau sempel tertentu, yang umumnya sempel diambil secara random dengan menggunakan instrumen penelitian sebagai pengumpulan data yang tujuannya sendiri adalah untuk menguji hipotesis yang sudah ditetapkan. Sedangkan penelitian asosiatif adalah alat untuk meneliti pengaruh atau hubungan antara dua variabel atau lebih yang dapat membangun suatu teori yang berfungsi untuk menjelaskan, meramalkan dan mengontrol suatu gejala yang membuat peneltian asosiatif mempunyai tingkatan tertinggi dibandingkan deskriptif dan komparatif (Sugiyono, 2016).

\section{TEKNIK ANALISIS DATA}

Teknik analisis yang digunakan dalam penelitian ini adalah menggunakan teknik analisis regresi linear berganda, statistik deskriptif, uji $\mathrm{t}$ (persial), uji validitas, uji realiabilitas, uji normalitas, uji heterokedastisitas, dan uji multikolinearitas.

\section{HASIL DAN PEMBAHASAN}

\section{Uji Validitas}

Uji validitas merupakan alat pengujian instrumen data yang bertujuan untuk mengukur ke absahan atau ke validan suatu kuesioner (Ghozali 2016). Uji validitas dilakukan dengan melihat apabila rhitung lebih besar dari rtabel maka instrumen yang akan digunakan valid atau sah. Namun, apabila rhitung lebih kecil dari rtabel maka instrumen yang akan digunakan tidak valid atau tidak sah. Adapaun alat uji yang digunakan dalam uji validitas ini yaitu Pearson correlation. Hasil uji validitas menggunakan uji pearson correlation menunjukan semua instrumen dalam penelitian ini valid atau sah dengan menghasilkan rhitung lebih besar dari rtabel sebesar 0,361 .

\section{Uji Reliabilitas}

Uji Realibilitas merupakan alat untuk mengukur kekonsistenan instrumen penelitian yang digunakan agar dapat dipakai untuk mengukur secara berkali-kali dengan hasil yang sehingga hasilnya konsisten (Sugiyono, 2013). Untuk menguji reliabilitas kuesioner dalam penelitian ini menggunakan rumus koefisien Alpha Crombach. Menurut Ghozali (2016) apabila koefisien Alpha lebih besar dari taraf signifikan $60 \%$ atau 0,6 maka kuesioner tersebut reliable, namun apabila koefisien Alpha lebih kecil dari taraf signifikan $60 \%$ atau 0,6 maka kuesioner tersebut tidak reliabel. Berdasarkan data yang diolah peneliti menunjukan bahwa variable bebas yang teridiri dari Ulasan Produk (X1) dan Foto Produk yang Ditampilkan Penjual (X2), serta variable terikat yatu Minat Beli Pria dan Wanita $(Y)$ masing-masing memiliki nilai Crombach alpha yang lebih dari 0,6 . Konidisi ini menunjukan bahwa seluruh variable tersebut 
adalah reliabel dan dapat di gunakan pada analisis selanjutnya.

\section{Uji Normalitas}

Uji normalitas merupakan alat untuk menguji kenormalan data. Selain itu tujuan dari uji normalitas yaitu untuk mengetahui apakah dalam metode regresi, variabel terikat dan variabel bebas keduanya memiliki distribusi normal (Ghozali, 2016). Peneliti menggunakan program SPSS dengan uji one sample kolmogrov smirnov untuk pengujian normalitas dalam penelitian ini. Pengukuran yang digunakan adalah dengan membandingkan nilai asymp. Sig (2-tailed) dengan nilai yang ditentukan sebesar 5\%. Apabila nilai asymp.Sig (2-tailed)lebih besar dari 0,05 maka dapat disimpulkan bahwa data tersebut berdistribusi normal. Berdasarkan hasil uji yang dilakukan peneliti menunjukan hasil dari uji normalitas dengan menggunakan OneSample Kolmogorov-Simirnov didapatkan hasil signifikansi sebesar 0,056 dimana hasil tersebitu lebih besar dari taraf signifikansi yang telah ditentukan yaitu 0,05 , sehingga dapat disimpulkan bahwa data yang digunakan peneliti berdistribusi normal.

\section{Uji Heterokedastisistas}

Uji heteroskedastisitas merupakan sebuah alat untuk menguji apakah terjadi ketidaksamaan varian dari residual satu pengamat ke pengamat lainnya dalam model regresi (Ghozali, 2016). Menurut Imam Ghozali (2016), untuk mendeteksi ada atau tidaknya heteroskedastisitas adalah dengan menggunakan pengujian Glejser dengan syarat jika nilai sig. diatas 0,05 maka tidak terjadi heteroskedastisitas. Berdasarkan hasil uji yang dilakukan peneliti menunjukan nilai signifikan dari ulasan produk sebesar 0,587 dan variabel foto produk yang ditampilkan penjual sebesar 0,521, yang artinya variabel independen dalam penelitian ini memiliki nilai signifikan lebih besar dari 0,05 . Dari data diatas dapat disimpulkan bahwa dalam penelitian ini tidak ada indikasi heterokedastisitas.

\section{Uji Multikolienaritas}

Uji multikolinearitas adalah alat uji yang digunakan untuk menguji model regresi apakah terdapat korelasi antar variabel bebas (Ghozali, 2016). Jika tolerance value $>0,10$ atau VIF $<10$ maka tidak terjadi multikolinearitas. Dalam penelitian ini penguji menggunakan SPSS 25. Berdasarkan hasil uji multikolinearitas yang dilakukan peneliti menunjukan bahwa varibel ulasan produk (X1) degan nilai tolerance 0,724 > 0,10 dan nilai VIF $1,381<10$. Maka dapat disumpulkan bahwa variabel bebas tidak terjadi multikolinearitas.

\section{Analisis Regresi Linear Berganda}

Analisi regresi linier berganda digunakan untuk mengetahui pengaruh Ulasan Produk(X1), Foto Produk yang Ditampilkan Penejual (X2) dan Minat Beli Pria dan Wanita (Y). Adapun persamaan yang diperoleh dalam penelitian ini adalah sebagai berikut:

$$
Y=a+b 1 X 1+b 2 X 2+e
$$

Berdasarkan hasil regresi linear berganda yang dilakukan peneliti dapat diketahui persamaan regresi sebagai berikut:

$$
Y=6.481+0,305 X 1+0,413 X 2 e
$$

Hasil persamaan regresi berganda di atas dapat memberikan pengertian sebagai berikut: a) Nilai konstanta sebesar 6.481 menunjukan bahwa ketika nilai variabel independen yaitu variabel ulasan produk dan foto produk yang ditampilkan penjual diasumsikan konstan atau diabaikan, maka nilai variabel $(\mathrm{Y})$ minat beli sebesar 6.481

b) Nilai koefisien regresi variabel bernilai positif yaitu 0,305 menunjukan apabila nilai ulasan produk mengalami kenaikan satu satuan sementara variabel independen lainnya diasumsikan konstan atau tidak berubah, maka nilai minat beli akan meningkat sebesar 0,305 satuan.

c) Nilai koefisien regresi variabel bernilai positif yaitu 0,413 menunjukan apabila nilai foto produk yang ditampilkan penjual mengalami kenaikan satu satuan sementara variabel independen lainnya diasumsikan konstan atau tidak berubah, maka nilai minat beli akan meningkat sebesar 0,413 satuan.

\section{7. $\quad$ Uji T (Persial)}

Uji $T$ yaitu alat uji yang dapat menunjukan seberapa jauh pengaruh satu variabel bebas secara individu dalam menjelaskan variasi variabel terikat (Ghozali, 2016). Pengujian dapat 
dilakukan dengan bantuan SPPS versi 25 dengan membandingkan nilai thitung dengan ttabel, dimana jika thitung $>$ ttabel dengan nilai signifikan < 0,05 maka Ha diterima dan Ho ditolak. Berdasarkan hasil pegujian yang dilakukan peneliti menjelaskan masing-masing variabel terhadap minat beli adalah sebagai berikut:

1. Variabel Ulasan Produk

Terlihat terdapat nilai sig $(0,015)<(0,05)$ dengan thitung (2.483) > ttabel(1.985) yang mana dapat disimpulkan bahwa Ha diterima dan Ho ditolak dimana artinya variabel $\mathrm{X} 1$ memiliki pengaruh terhadap Y. Jadi dapat disimpulkan ulasan produk memiliki pengaruh signifikan terhadap minat beli. Hasil penelitian ini selaras dengan penelitian Eun-Ju \& Yun Shin (2014) yang menyatakan dalam penelitian mereka bahwa kualitas ulasan yang baik memberikan pengaruh signifikan pada niat pembelian.

2. Variabel Foto Produk yang Ditampilkan Penjual

Terlihat terdapat nilai sig $(0,000)<(0,05)$ dengan thitung (3.666) > ttabel(1.985) yang mana dapat disimpulkan bahwa Ha diterima dan Ho ditolak dimana artinya foto produk yang ditampilkan penjual memiliki pengaruh signifikan terhadap minat beli. Hasil penelitian ini selaras dengan penelitian Xin L et al. (2016) yang menunjukkan hasil bahwa persentasi produk visual dapat mempengaruhi perilaku belanja konsumen ketika estetika visual disampaikan melalui foto produk yang dapat ditangkap dengan bantuan teknik pemrosesan gambar modern.

\section{Analisis Statistik Deskriptif}

Menurut Ghozali (2016) uji statistik deskriptif bertujuan untuk mendeskripsikan data dalam variabel yang dilihat dari nilai rata-rata (mean), minimum, maksimum dan standar deviasi. Uji statistik deskriptif merupakan statistika yang digunakan dalam mendiskripsikan data menjadi informasi yang lebih jelas serta mudah dipahami yang memberikan gambaran mengenai penelitian yang akan dilakukan.

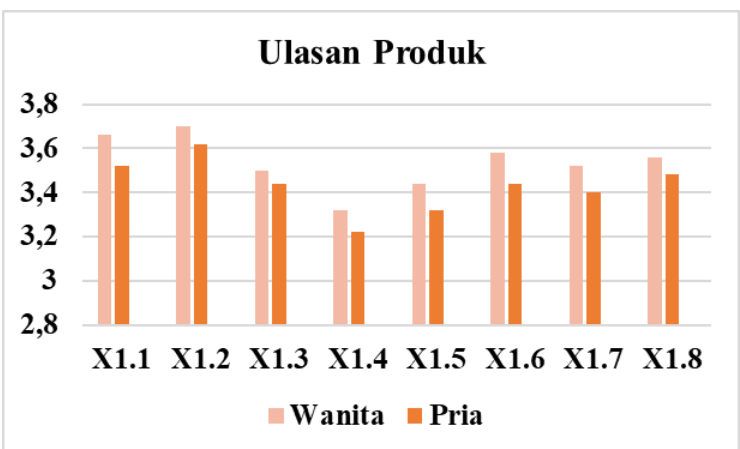

Sumber:output spps yang dijadikan grafik (data diolah peneliti)

\section{Gambar 4.1 Rata-Rata Pernyataan Ulasan Produk}

Dapat dilihat pada Gamber 4.1. wanita memiliki tingkat responsif yang lebih tinggi terhadap ulasan produk dengan nilai rata-rata lebih tinggi pada pernyataan 1 hingga pernyataan 8. Hasil penelitian ini selaras dengan penelitian dalam jurnal Kem Z.K. et al. (2014) yang membahas mengenai perbedaan gender dalam persepsi dan sikap terhadap ulasan yang tidak konsisten atau buruk di toko daring menemukan bahwa ulasan yang tidak konsisten atau buruk lebih mempunyai pengaruh yang signifikan terhadap wanita dari pada laki-laki.

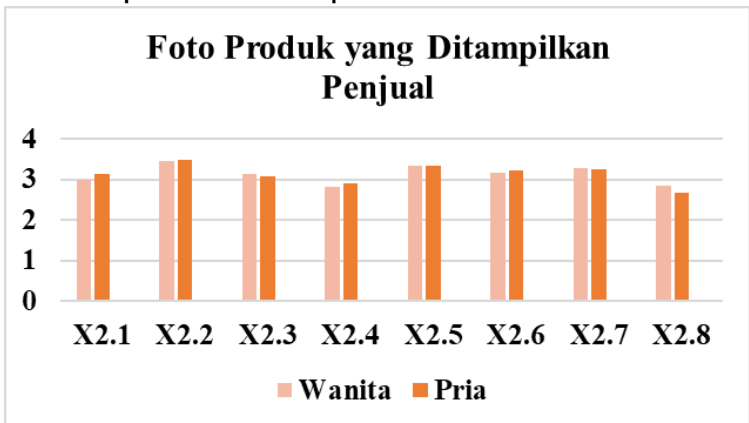

Sumber:output spps yang dijadikan grafik (data diolah peneliti)

\section{Gambar 4.2 Rata-Rata Pernyataan Foto Produk yang Ditampilkan Penjual}

Adapun untuk variabel foto produk yang ditampilkan penjual berdasarkan data pada Gambar 4.2. menunjukkan bahwa responden pria memliki tingkat responsif yang lebih tinggi terhadap foto produk yang ditampilkan penjual dengan nilai rata-rata yang lebih tinggi dihampir setiap pernyataan. Hasil penelitian ini selaras dengan penelitian dalam jurnal Xiaolin et al. 
(2018) menunjukan bahwa minat beli pria lebih dipengaruhi oleh interaktivitas situs web daripada wanita.

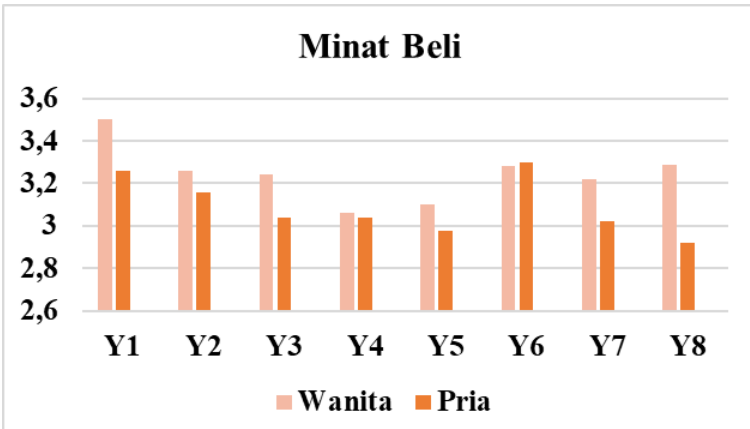

Sumber:output spps yang dijadikan grafik (data diolah peneliti)

Gambar 4.3 Rata-Rata Pernyataan Minat Beli

Berdasaran Gambar 4.3 di atas menjelaskan bahwa wanita memiliki minat beli yang lebih tinggi pada Marketplace Shopee dengan nilai rata-rata yang tinggi pada setiap pernyataan dari 4 indikator yang ditetapkan. Hasil penelitian ini selaras dengan penelitian Laksmitha dan Agung (2014) yang meneliti mengenai pengaruh perbedaan jenis kelamin dan kontrol diri terhadap keputusan pembelian impulsif produk parfum menunjukan bahwa konsumen perempuan memiliki kecendurangan yang lebih tinggi untuk melakukan pembelian impulsif dibandingkan dengan pria. Hal tersebut dapat terjadi dikarenakan wanita memiliki kontrol diri yang lebih rendah diandingkan pria. Selain itu ada juga faktor - faktor lain dari pengaruh jenis kelamin terhadap minat beli, yaitu tergantung pada jenis produk dan perusahaan harus menyadari perbedaan-perbedaan ini ketika merancang rencana pemasaran (Félix et al. 2015).

\section{PENUTUP}

\section{Kesimpulan}

1. Hasil pengajuan hipotesis pertama $(\mathrm{H} 1)$ menujukkan bahwa ulasan produk berpengaruh signifikan terhadap minat beli konsumen pada marketplace Shopee yang dibuktikan melalui hasil perhitungan uji t (persial) dimana nilai sig $(0,015)<(0,05)$ dengan thitung $(2.483)>$ ttabel(1.985). Artinya semakin banyak dan bagus ulasan produk pada suatu produk yang dijual pada Marketplace Shopee maka semakin orang berminat membeli produk tersebut.
2. Hasil pengujian hipotesis kedua $(\mathrm{H} 2)$ menunjukkan bahwa foto produk yang ditampilkan penjual berpengaruh signifikan terhadap minat beli konsumen pada marketplcae Shopee yang dibuktikan melalui hasil perhitungan uji t (persial) dimana nilai sig $(0,000)$ $<(0,05)$ dengan thitung $(3.666)>$ ttabel $(1.985)$. Artinya semakin bagus foto produk yang ditampilkan penjual pada pada Marketplace Shopee maka semakin orang berminat membeli produk tersebut.

3. Hasil pengujian hipotesis ketiga $(\mathrm{H} 3)$ menunjukkan bahwa wanita memiliki tingkat responsif yang lebih tinggi terhadap ulasan produk. Hal tersebut dibuktikan melalui hasil perhitungan uji statistik deskriptif yang menghasilkan nilai rata-rata responden wanita terkait ulasan produk sebesar 28,28 dan nilai rata-rata responden pria terkait ulasan produk sebesar 27,44. Yang artinya wanita cendrung akan lebih memperhatikan ulasan produk sebelum berbelanja untuk meningkatkan rasa percaya nya terhadap produk yang dilihatnya. Dengan demikian, hipotesis ketiga yang menyatakan bahwa wanita memiliki tingkat responsif yang lebih tinggi terkait ulasan produk, diterima.

4. Hasil pengujian hipotesis keempat (H4) menunjukkan bahwa pria memiliki tingkat responsif yang lebih tinggi terhadap foto produk yang ditampilkan penjual. Hal tersebut dibuktikan melalui hasil perhitungan uji statistik deskriptif yang menghasilkan nilai rata-rata responden pria terkait ulasan produk sebesar 25,08 dan nilai rata-rata responden wanita terkait ulasan produk sebesar 25,00. Yag artinya pria akan cendrung lebih memperhatikan foto produk yang ditampilkan penjual untuk membangun rasa percayanya terhadap produk yang dicarinya. Dengan demikian, hipotesis keempat yang menyatakan bahwa pria memiliki tingkat responsif yang lebih tinggi terkait foto produk yang ditampilkan penjual, diterima.

5. Hasil pengujian hipotesis kelima (H5) menunjukkan bahwa wanita memiliki tingkat minat beli yang lebih tinggi pada marketplace Shopee. Hal tersebut dibuktikan melalui hasil perhitungan uji statistik deskriptif yang menghasilkan nilai rata-rata responden wanita terkait minat beli sebesar 25,88 dan nilai rata-rata responden pria terkait minat beli sebesar 24,72. Artinya wanita cendrung lebih mudah 
terpengaruh dengan berbagai tawaran yang diberikan Marketplace Shopee sehingga membuat wanita tidak dapat menahan minat belinya pada suatu produk di Marketplace Shopee. Dengan demikian, hipotesis kelima yang menyatakan bahwa wanita memiliki tingkat minat beli yang lebih tinggi, diterima.

\section{Saran}

1. Penelitian selanjutnya yang memiliki fokus yang sama mungkin dapat menambahkan sample dan tambahan variabel seperti kualitas produk, harga produk, dan iklan. Penambahan sample dan tambahan variabel penelitian yang lebih banyak ini diharapkan agar dapat menghasilkan hasil pengujian yang lebih akurat mengenai peran ulasan produk dan foto produk yang ditampilkan penjual terhadap minat beli.

2. Perusahaan harus lebih memperhatikan dan mempertimbangkan apa saja yang dapat menarik atau menimbulkan minat beli konsumen. Dari hal tersebut perusahaan dapat meningkatkan hal apa saja yang dapat menarik atau menimbulkan minat beli konsumen tersebut agar perusahaan tetap stabil dan memiliki daya saing dengan kompetitor lain.

3. Masyarakat luas harus lebih teliti ketika ingin berbelanja daring yaitu dengan lebih memperhatikan ulasan produk ataupun foto produk yang ditampilkan penjual sehingga dapat mengurangi tingkat risiko penipuan atau ketidaksesuaian barang yang ditampilkan dalam katalog daring dengan barang aslinya.

\section{DAFTAR PUSTAKA}

Abebe, M. (2014). Electronic commerce adoption, entrepreneurial orientation and small-and medium-sized enterprise (SME) performance. Journal of Small Business and Enterprise, Vol. 21 (No.1), 100-116.

Anderson, Mayles (2013). "Study: $79 \%$ of Consumers Trust Online Reviews

As Much As Personal Recommendations". https://searchengineland.com/2013study-79-of-consumers-trust-onlinereviews-as-much-as-personalrecommendations-164565, diakses pada 20 November 2019 pukul 10.30 .

Anwar, Sanusi. (2011). Metode Penelitian Bisnis. Salemba Empat, Jakarta.

Arikunto, Suharsimi. (2013). Prosedur Penelitian: Suatu Pendekatan Praktik. Jakarta: Rineka Cipata.

Astari, Ni Putu Laksmitha Widya \& Widagda K, I Gusti Ngurah Jaya Agung. (2014). Pengaruh Perbedaan Jenis Kelamin dan Kontrol Diri TerhadapKeputusan Pembelian Impulsif Produk Parfum. E-Jurnal Manajemen Universitas Udayana. Vol. 3 (N0.3). 546-559.

Ayu, I Gusti Agung. et al.. (2019). Pengaruh Trust dan Easy of Use Terhadap Minat Beli Ulang Pada Marketplace Shopee di Kota Mataram. Jurnal Riset Manajemen Vol. 19 (No.1). 20 32

Bull, Stephen. (2010). Photography: Routledge Introductions to Media and Communication. London : Routledge

Cantrell, B. \& Yates, N. (2012). Modeling the Environment: Techniques and Tools for the 3D Illustration of Dynamic Landscapes. New Jersey: John Wiley \& Sons, Inc.

Danang, Sunyoto. (2013). Metodologi Penelitian Akuntansi. Bandung: PT Refika. Aditama Anggota Ikapi.

Di, Wei. et al.. (2014). Is a Picture Really Worth a Thousand Words? - On the Role of Images in E-commerce. Proceedings of the 7th ACM international conference. 633-642.

Diba, Dira Sarah. (2014). Pengaruh Kontrol Diri Terhadap Pembelian Impulsif Terhadap Remaja Berdasarkan Perbedaan Jenis Kelamin di Samarinda. eJournal Psikologi. Vol. 1 (No.3). 313-323.

Dr. Sudaryono, (2017). Pengantar Manajemen; Teori dan Kasus. Cetakan Pertama, Center fot Academic Publishing Service. 
Durianto, Darmadi (2013). Strategi Menaklukan Pasar Melalui Riset Ekuitas dan Perilaku Merek (cet. ke-10). Jakarta: PT Gramedia Pustaka Utama

Félix J., Ángel F., Julián. (2015). Influences of gender and product type on online purchasing. Journal of Business Research. Vol. 68 (No.7). 15501556.

Ferdinand, Augusty (2009),
Pengembangan Minat Merek
Ekstensi. Semarang: Badan
Penerbit Universitas Diponegoro.

Ghozali, Imam. (2016). Aplikasi Analisis Multivariete Dengan Program. IBM SPSS 23 (Edisi 8). Cetakan ke VIII. Semarang : Badan Penerbit Universitas Diponegoro

Goyette, I., Richard, I., Bergeron, I. \& Marticotte, F (2010). E-WOM Scale: Word ofMouth Measurement Scale for eService Context. Conadian Journal of Administrative Sciences. Vol: 27 (No.1). 5-23.

Herman Ph.D. (2017). Manajemen Pemasaran; Teori dan Aplikasi Pemasaran Era Tradisional Sampai EraModernisasi Global. Cetakan pertama, Alvabeta $\mathrm{cv}$. Bandung.

http://diglib.esaunggul.ac.id/public/UEU-paper6844-pertemuan 14.pdf, diakses pada 11 Oktober 2019.

http://m.facebook.com/pg/ShopeelD, diakses pada 27 September 2019

http://www.brandinstitute.com, diakses pada 11 Oktober 2019.

https://iprice.co.id/insights/mapofecommerce/ , diakses pada 1 November 2019.

http://www.konsultanstatistik.com/2009/03/ujiasumsi-klasik.html, diakses pada 18 Januari 2020

Indriantoro, Nur, Supomo \& Bambang. (2014). Metodologi Penelitian Bisnis Untuk Akuntansi \& Manajemen. Edisi 1. Cetakan ke-12. Yogyakarta: BPFE.

Kem Z.K., Christy M.K. \& Matthew K.O. (2014). Examining the Moderating Effect of Inconsistent Reviews and its Gender
Differences on Consumers' Online Shopping Decision. International Journal of Information Management. Hal 89-98.

Kotler, Philip \& Keller, Kevin Lane. (2016). Marketing Managemen, 15th Edition, Harlow: Essex Pearson Education Limited.

Kotler, Philip \& Keller, Kevin Lane. (2009). Manajemen pemasaran. Jilid 1. Edisi ke 13. Jakarta: Erlangga.

Kosasih, E. (2014). Jenis-jenis Teks Analisis Fungsi, Struktur, dan Kaidah Serta Langkah Penulisannya. Bandung: Yrama Widya.

Kristopher F., Ryan F., Saad A., Hyun Y. C. \& Traci F. (2014). How Online Product Reviews Affect Retail Sales: A Metaanalysis. Journal of Retailing. Vol. 2. 217-232.

Kustandi, Cecep \& Sutjipto, Bambang. (2013). Media Pembelajaran: Manual dan Digital. Bogor: Ghalia Indonesia.

Lee, Eun-Ju \& Soo Yun Shin. (2014). When do Consumers Buy Online Product Reviews? Effects of Review Quality, Product Type, and Reviewer's Photo. Computers in Human Behavior. Vol. 31. 356-366.

Margaretha, Fitri (2017). Analisis Hubungan Antara Motif Dengan Tingkat Kepuasan Pengguna Aplikasi Shopee Sebagai Media bereblanja Online Pada Shopeeholics di kota Samarinda. Journal Ilmu Komunikasi. Vol. 5 (No.4). 26-40.

Marcus, Sudjojo. (2010). "Tak-Tik Fotografi”. Jakarta: Bukune.

Martiyanti, Dwi. (2015). Perbedaan Gender Mengenai Perceived Risk Pada Pembelian Online. Jurnal Ekonomi Bisnis. Vol.12 (No.2). 140-149.

Nasution, Muhammad Fakhru Rizky \& Yasin, Hanifa. (2014). Pengaruh Promosi dna Harga Terhadap Minat Beli Perumahan Obama PT. Nailah Adi Kurnia Sei Mencirim Medan. Jurnal Manajemen \& Binsis. Vol. 14(No.2). 135-143 
Nugraha, Satya Utama. (2016). Analisis Foto Produk Fashion Pada Account Instagram Toidiholic. Skripsi Fakultas IImu Sosial dan IImu Politik Universitas Lampung Nathania.

Nuryaman \& Veronica, Christina. (2015). Metodologi Penelitian Akuntansi dan Bisnis, Teori dan Praktek. Bogor: Ghalia Indonesia

Notoatmodjo, Soekidjo. (2010). Metodologi Penelitian Kesehatan. Jakarta : Rineka Cipta

Pramono. et al.. (2012). Pertimbangan Dalam Membeli Produk Barang Maupun Jasa. Jakarta: Intidayu Press.

Riduwan. (2012). Metode \& Teknik Menyusun Proposal Penelitian. Bandung: Alfabeta

Rizki, M.F. \& Yasin, H. (2014). Pengaruh Promosi dan Harga Terhadap Minat Beli Perumahan Obama PT. Nailiah Adi Kurnia Sei Mencirim Medan. Jurnal Manajemen \& Bisnis. Vol. 14(No.2). 135-143

Slameto. 2010. Belajar dan Faktor-faktor yang Mempengaruhinya. Jakarta: PT Rineka Cipta

Stella (2018). Analisa pengaruh Online Consumer Review pada Keputusan Pembelian Generasi Milenial di Bandung (Studi pada Produk Gadget di Tokopedia). Skripsi Fakultas Ekonomi Universitas Katolik Parahyangan.

Sugiyono. (2017). Metode Penelitian Kuantitatif, Kualitatif, dan $R \& D$. Bandung : Alfabeta.

Sung H. H., Soon Y. B., Lee K. S. (2015). Impact of Online Consumer Reviews on Product Sales: Quantitative Analysis of the Source Effect. Applied Mathematics \& Information Sciences. Vol. 9 (No. 2). 373-387.

Turban. E., King. D., Lee. J. K., Liang, T. P. \& Turban, D.C. (2012). Electronic Commerce 2012; A Managerial and Social Networks Perspective Pearson education limited. New Jersey; Pearson Education.
Umar, Husein. (2013). Metode Penelitian untuk Skripsi dan Tesis. Jakarta: Rajawali.

Xiaolin L., Mauricio F., Stoney L. B., \& Nick H. (2018). Exploring Gender Differences in Online Consumer Purchase Decision Making: An Online Product Presentation Perspective. Information Systems Frontiers. Vol. 21 (No.5). 11871201.

Xin L, Mengyue W., Yubo C. (2014). The Impact of Product Photo on Online Consumer Purchase Intention: an Image-Processing Enambled Empirical Study. Computer Science. $1-14$

Yamin, Sofyan \& Kurniawan, Heri. (2014). SPSS Complete: Teknik Analisis Terlengkap dengan Software SPSS. Jakarta: Salemba Infotek 